\title{
Challenger Society
}

\section{BIBLIOGRAPHY \\ OF}

\section{MARINE FAUNAS}

$1846-1900$

EDITED BY

I. A. BORRADAILEE

SYNOPSIS OF THE CLASSIFICATION

CAMBRIDGE :

PRINTFD AT THE UNIVERSITY PRESS 


\section{Challenger Society}

\section{BIBLIOGRAPHY}

OF

\section{MARINE FAUNAS \\ 1846-1900}

EDITED BY

L. A. BORRADAILE

SYNOPSIS OF THE CLASSIFICATION

CAMBRIDGE :

PRINTED AT THE UNIVERSITY PRESS 


\section{$A S, B(2)$}

\section{CONTENTS.}

SCOPE OF THE WORK . . . . . . 3

Nature of the Areas . . . . . . . 3

Method of Classification . . . . . . 3

List of the Classes . . . . . . . 4

Definitions of the Areas a . . . . 9

Form of the Entries . . . . . . 16

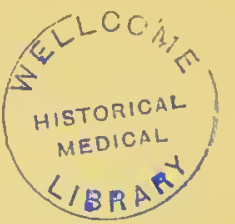




\section{BIBLIOGRAPHY OF MARINE FAUNAS.}

\section{SCOPE OF THE WORK.}

The Bibliography deals with the seas of the whole world, but not with marine forms in inland waters, and with all extant groups of the animal kingdom found in the sea, except the Seals, Sea-cows, Penguins, Turtles, Sea-snakes, amphibious Insects of the shore, and internal parasites. It is limited to the jears 1846-1900.

\section{NATURE OF THE AREAS.}

These correspond with natural faunas as nearly as is possible in our present state of knowledge of the latter, and in face of the necessity for easily definable and therefore arbitrary limits, and areas of a size which will divide the literature into manageable sections. They must not be regarded as an attempt to represent accurately the distribution of marine animals, but as a device for enabling the literature dealing with any given fauna to be obtained easily and as completely as may be.

\section{METHOD OF CLASSIFICATION.}

The principle adopted is that of the Decimal System. In this system the subject to be classified is divided into ten or fewer sections, denoted by the figures 0 to 9 , each section being similarly divided, and again each section of a section, to any required number of grades. By writing in order the figures which show respectively the position which each of a series of subordinated sections holds in the section which immediately includes it, a composite number is obtained which denotes any given section. Thus in the general classification of literature made by Dewey, the inventor of the system, and in use in the catalogue of the International Institute of Bibliography, and in many libraries, the primary divisions are as follows:

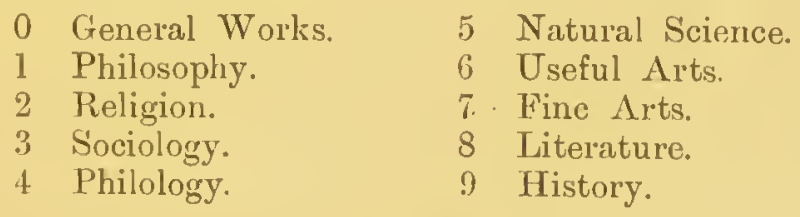

Natural science is again divided as follows:

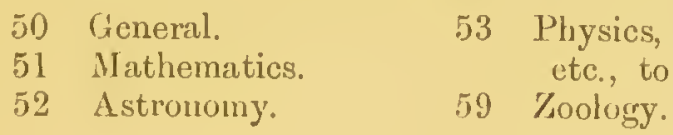


Zoology has 10 divisions, of which, e.g., 596 is Vertebrita. The zoological classification has been worked out in detail by the Concilium Bibliographicum of Zurich, and such portions of it as arc needed are used in the present bibliography. A detailed classification of the seas of the world has not yet been madc, and is attempterl here for the purposes of Marine Zoology. In accordance with the practice of the Concilium and the Institute, the geographical numbers are distinguished from the systematic by being enclosed in round brackets. The position of the present bibliography in the general system is as follows:

5 Natural Science.

9 Zoology.

1 The Zoological Disciplines.

9 Geographical Distribution.

(2 Physical Regions.

6) The Sea.

\section{LIST OF CLASSES.}

Numbers in square brackets are not in use alone, and are inserted only to explain those subordinate to them.

\section{Geographical Numbers*.}

$[5919(26 \ldots$

0)] World-wide. For works on the fauna of more than

(00) General. one Ocean.

(01) Plankton only, oceanic and neritic.

(03) Abyssal fauna (oceanic benthos) only.

(04) Oceanic fauna only, plankton and benthos.

The above figures $(.01, .03, .04)$ may be used to subdivide any of the Oceans or mixed areas below.

[(09)] For works limited to two neighbouring Oceans; without bathymetrical restrictions.

(09.1.3) Atlantic Ocean, North and Tropical.

(09.2.1) Mediterranean and North Atlantic Ocean.

(09.3.4) Tropical Atlantic and Southern Oceans.

(09.4.6) Southern Ocean and Eastern Pacific Occan.

(09.5.8) North Pacific and Arctic Oceans.

(09.6.5) Eastern and North Pacitic Oceans.

(09.7.2) Indopacific Ocean and Mediterranean Sca.

* For definitions of the "Occans" and "Arens," see below, pp. $9-16$. 
(09.7.4) Indopacific and Southern Occans.

(09.7.5) " "North Pacific Ocean

(09.7.6) " " Eastern Pacific Occan

(09.8.1) Arctic and North Atlantic Oceans.

(09.9.4) Antarctic and Southern Oceans.

[(1)] N. Atlantic Ocean.

(10) Morc than one area.

(11) Oceanic area.

(12) North Sea area.

(13) Baltic area.

(14) Azores area.

(15) Bermuda area.

(16) Lusitanian area.

(17) New England arca.

(18) Nor'wegian area.

(19) Icelandic area.

[(2)] Mediterranean.

(20) Nore than one area.

(23) Adriatic area.

(25) Black Sea area.

(26) Main Mediterranean area.

[(3)] Tropical Atlantic Ocean.

(30) More than one aret.

(31) Ocennic area.

(35) Caribbean area.

(36) W. African aren.

(37) Argentinian area.

(38) Brazilian area.

(39) Insular area.

[(4)] Southern Ocean.

(40) Nore than one arear.

(41) Oceanic area.

(43) New Zealand area.

(44) S. Australian area.

(45) Kcrguelen arca.

(46) S. African area.

(47) S. Georgian area.

(48) Magellanic area.

(49) Tristan da Cunha area.

[(5)] N. Pacific Ocean.

(50) Morc than one area.

(51) Oceanic area.

(52) Japanese area.

(55) Kamchatkan arca.

(57) Alaskan area.

(59) Californian area. 
[(6)] Eastein Pacific Ocean.

(60) More than one areit.

(61) Occanic area.

(67) Mexican area.

(68) Peruvian arcil.

(69) Insular area.

[(7)] Indopacific Ocean.

(70) More thin one area.

(72) Malay area.

(73) Mascarenc arca.

(74) Indian area.

(75) Red Sen area,

(76) E. African area.

(7 $\tau)$ N. Australian area.

(79) Polynesian area.

[(8)] Arctic Ocean.

(80) More than one area.

(81) Oceanic arca.

(84) Arctic European area.

(85) Arctic Asiatic arca.

(87) Arctic Amcrican area.

(8s) E. Greenland area.

(89) Librador area.

[(9)] Antarctic Ocean.

(90) More thin one area (i.e. oceanic with neritic).

(91) Ocennic area.

(92) Neritic area.

Group Nuarbers.

Taken, with omissions and additions, but without altcring the significance of any number, from the Conspectus of the Concilium Bibliographicum.

Divisions marked with an asterisk are inclusive of one or more that follow them, although they have as many figures in their classifying number as thesc subordinate groups.

[59]

0 VERTEBRATES AND 1NVERTEBRATES.

2* TNVertebirata.

[3] Lower Invertebrate Phyla.

31 Protozoa.

311* Rhizopoda (=Gymnomyxa). Amocboider. Mycetozoa.

312 Foraminifera.

313 Heliozoa.

314 Radiolaria.

$315^{*}$ Infusoria.

316 Flagellata (= Mastigophora).

317 Ciliata, including Acinetaria.

$3171 \quad$ Ciliata.

3175 Acinetaria (= Suctorii). 
$34 \quad$ Spongiae (= Porifera).

341 Myxospongiae (= Carnosin).

$3+2$ Ceratospongriace (- Ccratosa).

343 Monaxonicla (= Halichondrina + Spinarthrophora).

$3 \pm 4$ Tetractinellida.

345 Hexactinellida (- Hyalospongiae).

346 Calcispongiae (= Calcarea).

35* Coelenterata.

36 Actinozoa (= Anthozoa).

362 Alcyonaria (= Octactinia = Octocolallia).

363* Zoantharia (= Hcxactinia = Hexacorallia).

364

365

366

37

371

372

373

38

39

391

393

394

395

396

399

[4]

$40 *$

41

42

$43 *$

$+31$

432

4324

4329

434

435

438

44

45

$+52$ Antipatharia. Actinaria. Madreporaria.

Hydrozoa (= Hydromedusae + Acalephae). Hydromedusae, not including Siphonophora. Siphonophora.

Acalcphae.

Ctenophora.

Echinodermata.

Crinoidea.

Asteroidea.

Ophiuroidea.

Echinoidea.

Holothuroidea.

Enteropneusta (-Hemichorda). Mollusca and Molluscoida.

Mollusca.

Lamellibranehiata.

Scaphopoda.

Gastropoda.

Amphineura (= Isopleura), including Solenogastres.

Prosobranehia (= Streptoneura), not including Heteropoda. Aspidobranchia (= Diotoeardia).

Peetinibranchia (= Monotocardia), not including Heteropoda.

Heteropoda.

Opisthobranchia, not including Pteropodi.

Pulmonata.

Pteropoda.

Cephalopoda.

Tetrabranehiata (= Nautiloidea).

Dibranchiata.

Polyzoa (= Bryozoa), ineluding Pterobranehia.

Ectoprocta.

Pterobraneliia.

Entoproeta. 
is Brachipoda.

49 Tunicata.

491 Ascidiac, not including Copelatac or Pyrosonidae.

492 Copclatae (= Larvacea).

495 Pyrosomidac.

496 Salpidac.

497 Doliolidac.

[5] Articulata.

51 Vermes.

512 Platyhelminthcs, including Nemertina.

5122 Trematoda.

5123 Turbellaria.

5124 Nemertina.

513

5131

5132

5135

$514 *$

515

Nemathelminthes, including Chaetognatha.

Nematomorpha (Nectonematidae).

Nematoda.

Chaetognatha.

Annelida.

Hirudinea.

$516 \quad$ Oligochaeta.

[517] Marine groups of the Annelida.

5171 Archiannelida.

5172

5174

5176

Polychaeta.

5178

[518]

5181

5185

5189

$52 *$

53

$531 *$

Gephyrea (= Echiuroidea + Priapuloidea + Sipunculoidea).

\section{Phoronidae.}

Myzostomidae.

5315 Pantopoda (= Pycnogonida).

532

5323

5324

533

534

5341

5345

535

536 *

Rotifera, etc.

Rotifera.

Echinoderidae.

Dinophilidae.

Arthropoda.

Crustacea.

Entomostraca.

5361

537

5371

5372

538

Phyllopoda.

Branchipoda.

Cladocera.

Ostracoda.

Copepoda.

Gnathostomata.

Parasita.

Cirripedia.

Malacostraca.

Leptostraca.

Arthrostraca.

Amphipoda.

Isopoda, including Tanaidacca.

Thoracostraca. 


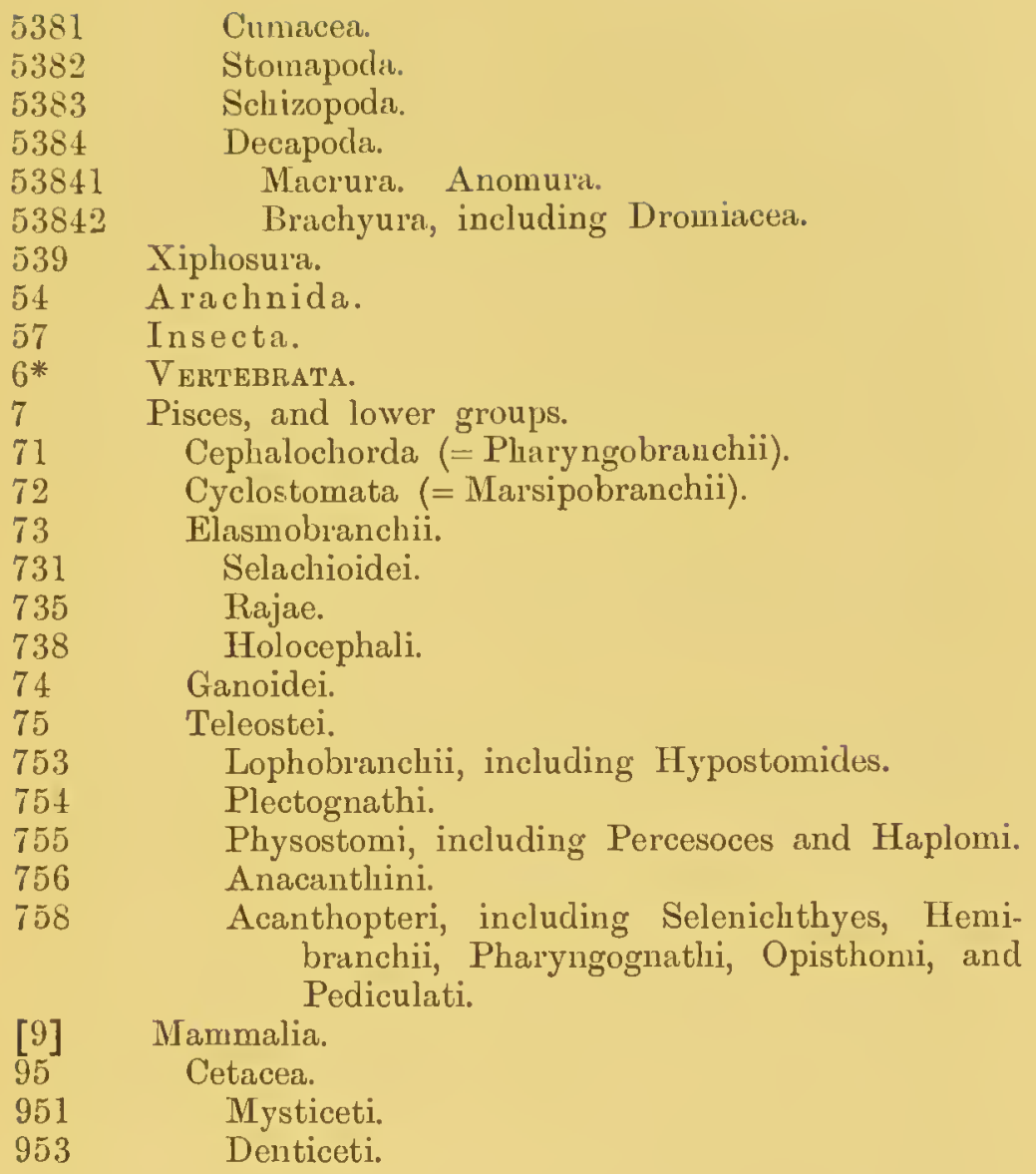

\section{DEFINITIONS OF THE AREAS.}

\section{$[(0)]$ World-wide.}

For works on the fauna of more than one Ocean.

(00) General.

For works not restricted to plankton (01), oceanic bentlos (03), or to any gcographical area.

\section{(01) Plankton.}

For works of a general scope on the plankton. Papers on planktonic groups not expressly treated as such under (00).

(03) Abyssal Fauna (Oceanic Benthos).

For works of a general scope on the fauma on or close above the bottom, outside the 100 fathom line. 
(04) Oceanic fauna.

For works of a general uature (n) thrs whole fauna of waters more than 100 fathoms in depth, i.c. occanic plankton and bentios.

Each of these pairs of figures $(.01, .03, .04)$, when adderl to the number for any of the Oceins or Areas containing deep water, indicates that the work in question is devoted exclusively to the fauna whicls it represents.

[(09)] For works limited to two neighbouring oceans. Without bathymetrical restrictions. Divided geographically by pairs of oceans, indicated by the ocean-numbers separated by points.

\section{(1) North Atlantic Ocean.}

Northern boundary: The 100 fatlom line on the European coast westwards from $43^{\circ} \mathrm{E}$. (Cape Kanin) till it meets the Arctic circle. The Arctic circle from this point to the 100 fathom line on the coast of Greenland, skirting the 100 fathom line north of Iceland. The 100 fathom line of Greenland to $60^{\circ} \mathrm{N}$. on the West coast. Lat. $60^{\circ} \mathrm{N}$. from the 100 fathom line of Greenland to the 100 fathom line of Labrador. The 100 fathom line of Labrador and Newfoundland to $60^{\circ} \mathrm{W}$. Thence a straight line to Cape Gaspé.

Westem boundary: The $\mathrm{N}$. American coast from Cape Gaspé to $30^{\circ} \mathrm{N}$. (immediately $\mathrm{N}$. of St Augustine).

Southern boundary: A line drawn from the American coast at $30^{\circ} \mathrm{N}$. to the junction of Long. $75^{\circ} \mathrm{W}$. with Lat. $25^{\circ} \mathrm{N}$. and thence to the Tropic of Cancer at $73^{\circ} \mathrm{W}$. The Tropic of Cancer till it reaches the African coast (immediately South of the Rio de Oro).

Eastern boundary: The African and European coast from the Tropic of Cancer to Cape Kanin crossing the Straits of Gibraltar by a straight line at its narrowest part.

\section{(11) Oceanic Area of the N. Atlantic.}

Every part of the Ocean not included in one of the areas below. More than 100 fathoms in depth, and therefore including the oceanic fauna only.

\section{(12) North Sea Area.}

All waters within the 100 fathom line from Ushant to the Skaw, including Rockall and the Porcupine Bank. Neritic only.

\section{(13) Baltic Area.}

The Baltic Sen within a line from the Slinw along the 100 fathom line to the Swedish-Norwegian boundary immediately South of Trederiksliald. Neritic only. 
(14) Azores Area.

All water's within the 100 fathom line of the Azores, Canary Islands and Maderia. Neritic only.

(15) Bermuda Area.

All waters within the 100 fathom line of Bermuda. Neritic only.

(16) Lusitanian Area.

All waters within the 100 fathom line from the Tropic of Cancel (immediately South of the Rio de Oro) to Ushant, excluding the Mediterranean. Neritic only.

(17) New England Area.

All waters within the 100 fathom line from Cape Gaspé to $30^{\circ} \mathrm{N}$. (immediately North of St Augustine). Neritic only.

(18) Norwegian Area.

All waters within the 100 fathom line of the Norwegialf and Russian coasts from Fretlerikshald northwards to $43^{\circ} \mathrm{E}$. (Cape Kanin). Neritic only.

(19) Icelandic Area.

All waters within the 100 fathom line of Iceland and within that of the Faroes. Neritic only.

(2) Mediterranean Sea.

All waters within the narrowest part of the Straits of Gibraltar, including the Black Sea and the Suez Canal.

(23) Adriatic Area.

The waters of the Adriatic north of a line from Cape Otranto to Cape Glossa. Neritic and oceanic.

(25) Black Sea Area.

All waters within the northern entrance to the Bosphorus. Neritic and oceanic.

(26) Main Mediterranean Area.

All waters of the Mediterranean except the Adriatic and Black Sea as defined above. Neritic and oceanic.

(3) Tropical Atlantic Ocean.

Northern boundary: The southern boundary of the North Atlantic, defined above.

Western boundary: The American coast from $30^{\circ} \mathrm{N}$. (inmediately North of St Augustine) to the point where $66^{\circ}$ L. crosses it. 
Southern boundary: $45^{\circ} \mathrm{S}$. from $66^{\circ} \mathrm{E}$. to $20^{\circ} \mathrm{E}$. and thence $32^{\circ} \mathrm{S}$. to the $A$ fricun coast (immediately North of Lambert's Bay).

Eastern boundary: The African eoast line between the Tropics of Cancer and $32^{\circ} \mathrm{S}$.

(31) Oceanic Area of the Tropical Atlantic.

Every par't of the Ocean not included in one of the A reas below. Oceanic only.

(35) Caribbean Area.

The Gulf of Mexico and the Caribbean Sea inside a line drawn from $30^{\circ} \mathrm{N}$. to the junction of Long. $75^{\circ} \mathrm{W}$. with Lat. $25^{\circ} \mathrm{N}$., thence to the junction of Long. $68^{\circ} \mathrm{W}$. with Lat. $20^{\circ} \mathrm{N}$., thence along Lat. $20^{\circ} \mathrm{N}$. to its junction with Long. $60^{\circ} \mathrm{W}$., and thence to the junction of Long. $60^{\circ} \mathrm{W}$. with the $\mathrm{S}$. American coast at Barima, passing outside Barbadoes. Neritie and oceanic.

(36) W. African Area.

The coastal waters of West Africa between the Tropic of Cancer and $32^{\circ} \mathrm{S}$, and of the Islands in the Gulf of Guinea. Neritic only.

(37) Argentinian Area.

The S. American coastal waters within the 100 fathom line from $45^{\circ} \mathrm{S}$. (Cape Dos Bahias) to Montevideo ( $35^{\circ} \mathrm{S}$.). Neritie only.

(38) Brazilian Area.

The S. American coastal waters within the 100 fathom line from $60^{\circ} \mathrm{W}$. at Barima to Montevideo $\left(35^{\circ} \mathrm{S}\right.$.). Neritic only.

(39) Insular Area of the Tropical Atlantic.

Waters within the 100 fathom line round Ascension, Cape Vercle Islands, Fernando Noronha, St Helena, St Paul's Rocks, and Trinidad. Neritic only.

\section{(4) Southern Ocean.}

Northern boundary: In the Atlantic the southern boundary of the Tropical Atlantic, defined above. In the Indian and Pacific Oceans $32^{\circ} \mathrm{S}$.

Southern boundary: $60^{\circ} \mathrm{S}$.

(41) Oceanic Area of the Southern Ocean.

Every part of the Ocean not included in one of the areas below. Oceanic only.

\section{(43) New Zealand Area.}

All waters within the 100 fathom line round the islands of New Zealand, the Antiporles, Auckland, Campbell, Chatham, and Macquarie. Neritic unly. 
S. Australian Area.

All waters within the 100 fathom line round Australia south of $32^{\circ} \mathrm{S}$. and Tasmania, and round Royal Company Island. Neritic only.

\section{(45) Kerguelen Area.}

All waters within the 100 fathom line round Kerguelen, Amsterdam and St Paul, Crozet, Hearl, Marion, and Prince Edward Islands. Neritic only.

(46) S. African Area.

All waters within the 100 fathom line round Africa south of $32^{\circ} \mathrm{S}$. Neritic only.

\section{S. Georgian Area.}

All waters within the 100 fathom line round S. Georgia, the Sandwich group, Dougharty, and Bouvet Islands. Neritic only.

\section{(48) Magellanic Area.}

All waters within the 100 fathom line round S. America and the Falkland Islands, from $45^{\circ} \mathrm{S}$. on the eastern side to $32^{\circ} \mathrm{S}$. on the western side, and round Juan Fcrnandez. Neritic only.

\section{(49) Tristan da Cunha Area.}

Waters within the 100 fatlom line round Gough, and Tristan da Cunha Islands. Neritic ouly.

\section{(5) North Pacific Ocean.}

Northern boundary : Lat. $60^{\circ} \mathrm{N}$. between Kamchatka and Alaska, excluding Nunivak Island.

Western boundary: The coast of Asia from $60^{\circ} \mathrm{N}$. to Hang-Chau Bay.

Southern boundary: A line from Hang-Chau Bay to Lat. $30^{\circ} \mathrm{S}$., passing south of the Chusan Islands. Along $30^{\circ} \mathrm{N}$. to the 100 fathom line of Japan, and northward along the 100 fathom line to $40^{\circ} \mathrm{N}$. Thence along $40^{\circ} \mathrm{N}$, to the 100 fathom line of the American coast. Along the American 100 fathom line to Cape St Lucas.

Eastern boundary: The American coast line from $60^{\circ} \mathrm{N}$. to Cape St Lucas.

\section{(51) Oceanic Area of the North Pacific.}

Every part of the Ocean not included in one of the Arcas below. Oceanic only.

\section{(52) Japanese Area.}

From $30^{\circ} \mathrm{N}$. to the middle of the Tsugaru Straits within the 100 fathom line outside Japan, including the Sen of Japan as far north as the Tsugaru Straits. Neritic and occanic. 


\section{(55) Kamchatkan Area.}

From the Tsugaru Straits to $60^{\circ} \mathrm{N}$. within the 100 fathom line outside Kamchatka, including the Sea of Okhotsk. and of the Sea of Japan north of 'Isugaru Straits, and Bering and Komandorski Islands. Neritic and oceanic.

\section{(57) Alaskan Area.}

All waters within the 100 fathom line of the American coast from $60^{\circ} \mathrm{N}$. to San Juan de Fuca Straits, including the Aleutian and Pribyloff Islands but not Nunivak Island. Neritic only.

\section{(59) Californian Area.}

All waters within the 100 fathom line of the American coast from San Juan de Fuca Straits to Cape St Lucas. Neritic only.

\section{(6) Eastern Pacific Ocean.} $32^{\circ} \mathrm{S}$

Western boundary: $110^{\circ} \mathrm{W}$. from Cape St Lucas to

Eastern boundary: The American coast line from Capc St Lucas to $32^{\circ} \mathrm{S}$.

\section{(61) Oceanic Area of the Eastern Pacific.}

Every part of the Ocean not included in one of the Areas below. Oceanic only.

\section{(67) Mexican Area.}

All waters within the 100 fathom line of the Amcrican coast from Cape St Lucas to $5^{\circ} \mathrm{S}$. and of the islands near the coast. Neritic only.

\section{(68) Peruvian Area.}

All waters within the 100 fathom line of the American coast from $5^{\circ} \mathrm{S}$. to $32^{\circ} \mathrm{S}$. Neritic only.

(69) Insular Area of the Eastern Pacific.

All waters within the 100 fathom line round Clipperton, Cocos, Easter, the Galapagos, Malpelo, St Felix, and SalaryGomez Islands. Neritic only.

(7) Indopacific Ocean.

Northern boundary: The southern coast line of Asia and the southern boundary of the N. Pacific Occan as detined above.

Western boundary: The eastern coast line of Africa to $32^{\circ} \mathrm{S}$.

Southern boundary: $32^{\circ} \mathrm{S}$.

Eastern boundary: The 100 fathom line of the Amcrican coast line from $40^{\circ} \mathrm{N}$. to Cape St Tucas, and thence $110^{\circ} \mathrm{W}$. to $32^{\circ} \mathrm{S}$. 
(72) Malay Area.

Northern boundary: The coast line of Asia from the mouth of the Irawadi to $30^{\circ} \mathrm{N}$. Thence the southern boundary of the N. Pucific as defined above.

Western boundary: $95^{\circ} \mathrm{E}$. from the mouth of the Irawadi to $32^{\circ} \mathrm{S}$.

Southern boundary: $32^{\circ} \mathrm{S}$. from $95^{\circ} \mathrm{E}$. to the 100 fathom line of the Australian coast. This line from $32^{\circ} \mathrm{S}$. to $10^{\circ} \mathrm{S}$. and along $10^{\circ} \mathrm{S}$. to the Torres Straits, where it follows the political boundary, passing to the north of all the islands and close to the New Guinea shore. Thence the 100 fathom line of Australia to $32^{\circ} \mathrm{S}$. and $32^{\circ} \mathrm{S}$. to $170^{\circ} \mathrm{E}$.

Eastern boundary: North of the Equator $160^{\circ}$ E., including the Caroline group. South of the Equator $170^{\circ} \mathrm{E}$., including the New Hebrides. Neritic and oceanic.

(73) Mascarene Area.

The cleep water of the Indian Ocean west of $95^{\circ} \mathbf{E}$, with all the Oceanic islands. Ncritic and oceanic.

\section{(74) Indian Area.}

All waters within the 100 fathon line from the mouth of the Irawadi to the Straits of Bab el Mandeb. Neritic only.

(75) Red Sea Area.

Including waters of all depths, but not including the Suez Canal. Neritic and oceanic.

(76) East African Area.

All waters within the 100 fathom line along the African const from Bab el Mandeb to $32^{\circ} \mathrm{S}$, including Socotra. Neritic only.

(77) North Australian Area.

All waters within the 100 fathom line of the Australian coast north of $32^{\circ} \mathrm{S}$. Neritic only.

(79) Oceanic Area.

Northern boundary: $40^{\circ} \mathrm{N}$.

Western boundary: The eastern boundary of the Malay A rea, defined above.

Southern boundary : $32^{\circ} \mathrm{S}$.

Eastem boundary: The 100 fathom line of the American coast from $40^{\circ} \mathrm{N}$. to Cape St Lucas, and thence the $110^{\circ} \mathrm{W}$. line to $32^{\circ} \mathrm{S}$.

Neritic and oceanic.

(8) Arctic Ocean.

Bounded by the coasts of Europe, Asia, and America, and by the northeru boundaries of the Atlantic and Pacific Occans, as defined above. 


\section{(81) Oceanic Area of the Arctic Ocean.}

Wrery part of the Occan not included in one of the arens below. Ocennic only.

(84) Arctic European Area.

All water's within the 100 fathom line of the northern coast of Europc, East of $43^{\circ} \mathrm{E}$. (Cape Kanin), including Novaya Zemlya, and of Spitzbergen, Franz Josef Land, and Bear Island. Neritic only.

(85) Arctic Asiatic Area.

All waters within the 100 fathom line of the northern coast of Asia, including New Siberia and Wrangel Islands. Neritic only.

(87) Arctic American Area.

All waters within the 100 fathom line of the northern coast of America and the adjacent islands as far south as Cape Chudleigh, including the west coast of Greenland, and the deep water of Baffin's Bay and its offshoots. Neritic and oceanic.

(88) East Greenland Area.

All waters within the 100 fathom line of the east coast of Greenland and of Jan Mayen Island. Neritic only.

(89) Labrador Area.

All waters within the 100 fathom line of the American coast from Cape Chudleigh to Cape Gaspé. Neritic only.

(9) Antarctic Ocean.

South of $60^{\circ} \mathrm{S}$.

(91) Oceanic Area of the Antarctic Ocean.

All the Antarctic Ocean outside the 100 fathom line.

(92) Neritic Area of the Antarctic Ocean.

All the Antarctic Ocean within the 100 fathom line.

\section{FORM OF THE ENTRIES.}

The Bibliography has two series of entries, arranged respectively in order of geographical numbers and of group numbers. Every work is entered in both series. Each entry contains: (1) a geographical number or a group number, (2) a group number or a geographical number, (3) the author's name, (4) reference to pages in a journal or the name of a book, (5) the date of publication. Whenever possiblc a word or phrase is added to the geographical or group number to give an exact locality, species, or other information. 


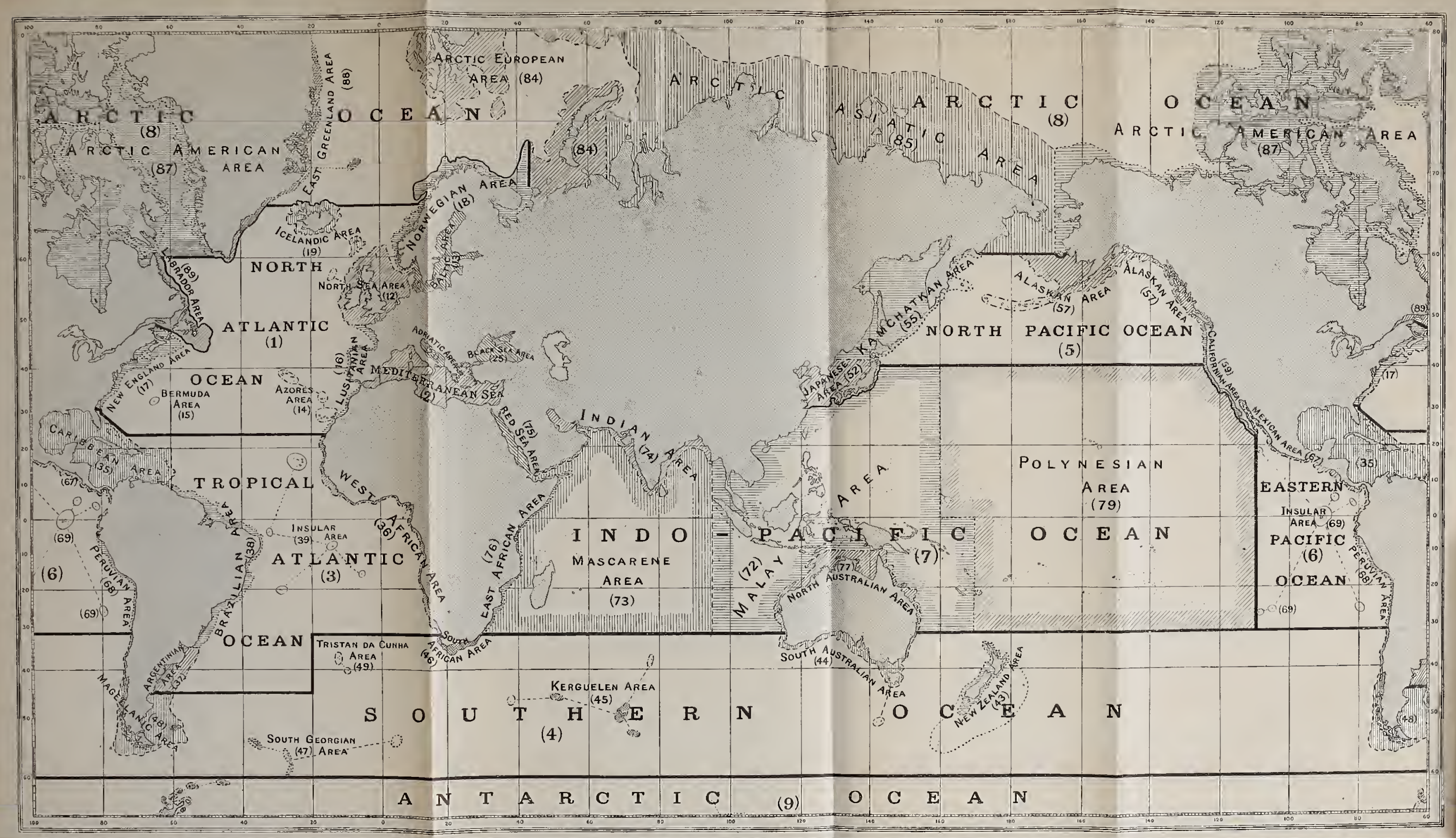



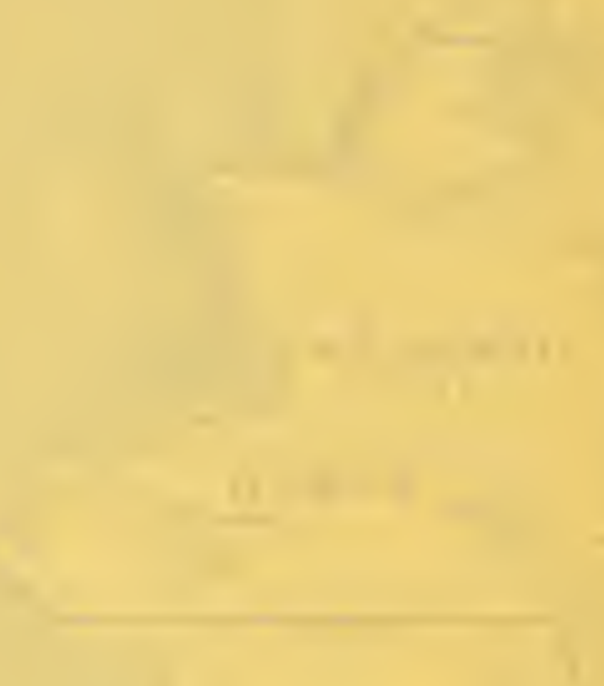

$+2$
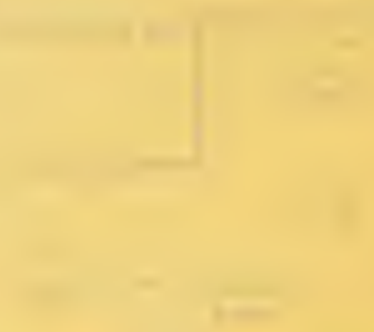

